\title{
Islamic Boarding Schools As Means Of Regeneration In The Development Of Da'wah
}

\author{
Mahmud Fauzi \\ The Jakarta Islamic University \\ Correspondent: mfauzisuali@gmail.com
}

Submitted : Juny 30, 2020 Revised : July 15, 2020 Published : Juli 30, 2020

\begin{abstract}
Islamic boarding schools as a means of regeneration in the development of da'wah. Islamic boarding school is an educational institution that transforms the value of education and example every second and minute and every time from a kyai to his students. Researchers are interested in choosing this topic because no one has conducted research with the same title. It is hoped that the benefits of the research will be of assistance to the pesantren pindok caregivers as well as for prospective $d a^{\prime} i$ who wish to further deepen various dakwah sciences. The reason other researchers are not interested in this title is that they consider Islamic boarding schools as a means of regeneration in the development of $d a^{\prime} w a b$ to be ineffective and not optimal. Apart from this research, the writer tries to find a formula for what is done by the Islamic boarding schools to regenerate candidates and those who have become $d a^{\prime} i$, forged to become qualified $d a^{\prime} i$. This research was conducted using field research (field research) and qualitative analysis. Therefore, the data collected in this study is in the form of information in the form of descriptions. Qualitative analysis is considered more appropriate in this study, because this analysis is expected to make it more possible to develop this research in order to gain a deeper understanding. Research findings of Islamic boarding schools have a function as a da'wah institution, have elements and systems that are ideal in producing $d a^{\prime} i$ cadres who have broad knowledge and character. Conclusion of the study, Islamic boarding school as a means of regeneration that prepares the next generation of Islam, through the provision of knowledge (leadership, management and insight) in stages and careful planning. The implication of this research is that the cadre model in the development of da'wah in Islamic boarding schools which is deliberately designed in such a way, it is certain that the $d a^{\prime} i$ cadres can develop the knowledge they have and are ready to preach Islamic values wherever they are.
\end{abstract}

Keywords: Islamic boarding schools, regeneration, development, Da'wah

\section{INTRODUCTION}

The development of religious education through Islamic boarding schools has grown and developed since approximately 700 years ago. Pesantren have their own education pattern [1] and it is different from the education pattern in general. The Islamic boarding school education pattern has its own variety and character, between one Islamic boarding school and another Islamic boarding school has its own ways and methods. Although there are different ways of education, they have the same goal, which is to humanize humans with the guidance of al-Qur'an and al-Hadith.

The superiority of Islamic religious education institutions in Islamic boarding schools which have become the prima donna in the world of education to date, is because the curriculum offered is not only for pursuing material alone, but Islamic religious education at Islamic boarding schools provides an example in the learning process which is one part of da'wah. While 
on the other side of the boarding school which is the center of exemplary from a kyai to his students who interact with each other approximately twenty-four hours.

According to Mastuhu [2] Islamic boarding schools are a traditional Islamic educational institution to study, understand, deepen, appreciate, and practice Islamic teachings by emphasizing religious morals as guidelines for daily behavior. Islam is a missionary institution, not only do many advocate to disseminate the truths as contained in Islam, even obliging its adherents to do this da'wah task, there is no better word for Muslims, except for words calling for the mischief of Allah, then the task of spreading the truth of Islam is an integral part of the soul and life of a Muslim. [3]

The doctrine of Islamic da'wah, was revealed by the al Qur'an itself and proven through the historical records of the Prophet Muhammad, friends, and scholars. Da'wah literature, textual arguments that refer to it are usually contained in the discussion of da'wab obligations. The Qur'an, for example, instructs Islam to prepare a special committee that works as a preacher, or requires da'wah as a way to create an ideal society.[4]

Da'wah is an integral part of the teachings of Islam which must be carried out by every Muslim. This obligation is reflected in the concept of amar ma'ruf and nabi munkar, which is an order to encourage people to engage in positive-constructive behavior while at the same time inviting them to leave and distance themselves from negative-destructive behavior. This concept contains a deep meaning, namely the principle of struggle to uphold the truth in Islam and to actualize Islamic truth in social life in order to save them and the environment from damage. [5]

Based on the purpose of its establishment, Islamic boarding schools exist based on at least two reasons: first, Islamic boarding schools were born to respond to the social situation and conditions of a society that is facing the collapse of moral principles, through the transformation of the values it offers (amar ma'ruf and nabi munkar). Thus its presence can be called an agent of social changes which always liberates society from all moral evils, political oppression and economic poverty. Second, one of the goals of education in Islamic boarding schools is to disseminate information about the universality of Islamic teachings throughout the archipelago with a pluralist character, both in the dimensions of beliefs, culture and social conditions of society [6]

From the above problems it can be understood that da'wah requires regeneration of professional $d a^{\prime} i$ cadres, who are able to answer religious and social problems today. Because of this, the preaching of cadre will be very useful for the continuity of preaching in the present or future. $D a^{\prime} i$ cadres are: people who are trained and prepared through kererisasi to continue the $d a^{\prime} w a h$ activities of the previous generation. $D a^{\prime} i$ cadres must be trained so that they have scientific or methodological competence and the objectives of preaching can be fulfilled well.

The definition of Islamic boarding school according to the Law of the Republic of Indonesia number 18 of 2019 concerning Pesantren [7] explains that what is meant by pondok pesantren, dayah, surau, meunasah, or other terms hereinafter referred to as pesantren is a communitybased institution established by individuals, foundations Islamic community organizations, and/or communities that instill faith and devotion to Allah SWT., promote noble morals and uphold the Islamic teachings of rahmatan lil'alamin which are reflected in the attitude of heart, tolerance, balance, moderation, and other noble values of the Indonesian nation through education, Islamic preaching, exemplary, and community empowerment within the framework of the Unitary Republic of Indonesia. 
The definition of means is a tool that can be used to facilitate or facilitate humans in achieving certain goals. Means are directly related and become the main support in an activity. Means can take the form of movable and immovable objects and are generally small in shape and can be moved. [8]

While cadre or cadre according to the Big Indonesian Dictionary is a process, method, act of educating or forming a person to become a cadre. While cadres are people who are expected to play an important role in government, parties, and so on. [9]

Based on some of the above definitions, it can be concluded that the means of regeneration is a place used (students/prospective $d a^{\prime} \imath$ ) to transfer values both general and specific values (da'wah material) carried out by educational institutions or institutions. The values given contain materials on leadership, management, basic and related principles or institutions. This is a provision for $d a^{\prime} i$ cadres in continuing the sustainability of educational institutions in Islamic boarding schools.

Development is a science and technology activity that aims to utilize proven principles and theories of science and technology to improve the functions, benefits and applications of existing science and technology or to produce new technologies. Development is a process used to develop and validate educational products. [10]

While the etymological definition of $d a^{\prime} w a h$, the word $d a^{\prime} w a h$ is a masdar form of the words yad'u (fi'il mudhari') and da'i (fi'il madii) which means to call, invite (to invite), invite (to summer), called (to propo), pushed (to urge) and begged (to prray). In addition to the word "da'wab", the al Qur'an also mentions a word that has a similar meaning to "preaching", namely the word "tabligh" which means delivery, and "bayan" which means explanation. (11)

According to the author, the definition of da'wah development is a process of designing learning (delivering da'wab) of Islamic teachings logically and systematically in order to determine everything that will be carried out in the process of learning activities both in educational institutions and in society.

The main form of $d a^{\prime} i$ regeneration is Mubadharoh, which is one of the tools so that students become preachers, to carry out the program at the Ar-Risalab Islamic boarding school, this muhadharoh is needed as a mandatory program in the $A r$-Risalah Islamic boarding school which is held to shape character into a good preacher, this program is held twice a week and is included in the flagship program at the boarding school.

The word $d a^{\prime} i$ comes from the Arabic form mudzakar (male) means person who invites, if muannas (woman) is called da'iyah. Da'i can also be interpreted as people whose work is da'wah, propagating the Islamic religion. In other words, preachers are people who invite either directly or indirectly, through oral, written, or deed to practice Islamic teachings, or spread Islamic teachings, and make efforts to change towards a better condition according to Islamic teachings.[12]

Muhadhoroh is a speech practice prepared to become a $d a^{\prime} i$ which is held on Monday and Friday nights which must be followed by all students of the Ar-Risalah Islamic boarding school. The form of regeneration in the Ar-Risalah Islamic boarding school can be seen from the following three competencies: [13]

\section{Basic Competence}

a. Character building. Since the beginning of entering the Ar-Risalah boarding school, the students have been trained or formed to have good character, have been taught good manners, manners for the elders, polite eating and good manners, these are the 
basics character before becoming a preacher.

b. Training in the Value of Faith and Devotion. The main training that is no less important is the training to instill the values of faith and piety. Among them are training programs that are instilled in students, namely cleanliness of part of the faith, students are trained independently and neatly in clothes, neat in the beauty of the rooms, closets, and neatness of the arrangement of books, no santri can be lazy to be responsible for cleanliness, all will be trained and if they violate they will be subject to sanctions. Furthermore, the practice of cultivating piety among students takes place continuously, for example, the discipline of obligatory prayer and midnight prayer, all students are obliged to be qiyamul lail, merit to Allab in one third of the night, this training is compulsory for all students from the initial class to the final class.

c. Scientific Seeking Training. This training for students begins with constructing students to love books, the program in particular is that all students are required to have all textbooks in the ongoing lesson, this will be accounted for when approaching the class promotion exam, students who do not have books, or the entire textbook is incomplete. not allowed to take exams, from this rule slowly making students have a lot of books when they graduate from the Ar-Risalah Islamic boarding school because they are required to have all textbooks, so that ultimately the students love science more because the books they have can be reread at home.

d. Tawadhu Attitude Training. Even though the $A r$-Risalab Islamic boarding school is a modern Islamic boarding school with all the facilities available, this boarding school trains its students to keep it simple, visible from the daily food menu, each of which has been well scheduled, not a very special meal, but simple but nutritious, taking food in line and regularly, it becomes training in the value of tawadhu ' among students.

2. General competence. Before the mubadharoh event took place at the Ar-Risalah Islamic boarding school, it was known that pre mubadharoh was the preparation before the mubadharoh event took place the pre mubadharoh process starting from the consolidation of the board of the santri organization who had just been appointed as the board with a language consultant.

a. Opening and Closing Speech Training. The part of the organization that is responsible for the implementation of the mubadharob event is known as the banansa or the language section, the banansa section is an important part of the organizational management of the Ar-Risalah Islamic boarding school, where this part is like the heart of the implementation of three language flagship programs at the Ar-Risalah Islamic boarding school.

The technique of opening speech starts with greeting, followed by muqaddimah, prayer and the title. The content of the padato is made attractive by the students who can be corrected by the practicing muallim, the intonation must be clear and pronounce it in a gentle valley or according to the theme, thus in the closing it is arranged in such a way.

b. Material Delivery Communication Training. The provision and communication training for cadre $d a^{\prime} i$ in this case is mubadharoh under the responsibility of Markazul Lughat, a forum that is under the education bureau. Markazul lhughat, all this time holding mudharoh events twice a week. In addition to the mentors and markazul lughat 
(ustad) with the field implementers by the Islamic boarding committee of the boarding students and must be followed by all students of the boarding school Ar-Risalah, for each class or per class.

c. Material Delivery Psychologist Training. Mental training at the Ar-Risalab Islamic boarding school to strengthen the $d a^{\prime} i$ cadre program, especially for the highest class, there is leadership training. Mubadbaroh is part of the language program held by banansa, the muhadharoh event from 20:00 to 21:00 begins with a large bell that must be started. These runitas have been grouped by the appointed Ismi banansa, students are obliged to make $i^{\prime} d a d$ first, the organizer of the event writes about the text presented, writes the verses of the al Qur'an and must be memorized, if not memorized it does not get the signature of the muallim, in order to mentansrib (see whether or not) it is deposited to the muallim no later than the afternoon before performing, after that the memorization practice in front of the new muallim can be signed and stamped banansa. Wait for the bell muallim to give a signal to start each mubadharoh in the first bell, the $M C$ starts the event by reading the arrangement of the program. Schedule the students to become MC, Qori', speech tuga language (Arabic, English and Indonesian) in each group for one semester (balf a year), the students must make an $i^{\prime} d a d$ before appearing and ask for signatures from the muallim banansa for students who have schedule appears to test feasibility before performing. Each room consists of a room supervisor (muallim), one MC, one Qori ', three speeches and students according to their respective division led by the MC and under the responsibility of the room supervisor (muallim) of each room (each room consists of the two room supervisors). Appoint the students who do not have a schedule to appear to take the essence/conclusion of every single speech which the MC points out to the students in that room spontaneously without discrimination/class.

\section{Special Competence}

a. Speech Explanation Training. This training is specifically conducted by the ROC (Rhetoric Orator Club) is a group of elite muhadharoh consisting of students who have special abilities in muhadharoh, related students recruited specifically by experienced tutors who also have special abilities, there are three lines of Indonesian ROC section, The Arabic language ROC, and the English ROC, the screening to become members is also through a difficult process, it requires special observation from the part of Ismi who is supported by Markazul Lughoh, so that it can give birth to the elite mubadharoh club, in its implementation it has the same time as mubadbarob in general, namely on days. Monday and Friday at 20:00 to 21:00, the fundamental difference from the students of mubadharoh in general is that the content of mubadharoh looks more skilled because the training also exceeds ordinary mubadharoh, the application of discipline in mubadharoh still applies as usual ie members must ask for autographs to muallim as a form of agreement The text to be displayed is appropriate, if there is no proof of the muallim's signature, the santri will be sanctioned by echoing for following mubadharoh. Next is mubadharoh akbar, a speech practice event that is carried out simultaneously by all students who are only filled with a few performers, who are incidental and prepared to the maximum by muhadharoh actors, this big event is usually filled with students who already have special skills in making good speeches from the language Arabic, English and Indonesian. 
b. Training Delivers Fun Material. Muhadharoh is a preaching cadre activity which is fun, they are trained seriously but also in a relaxed and fun way. So that the audience who listens to the content or lecture material of a preacher is not saturated.

\section{METHODS}

The approach used in this research is a qualitative approach, namely research procedures that produce descriptive data in the form of references or writing and behaviors that can be observed from the person (subject) itself. [14] With this qualitative research, the researcher will make a descriptive description of the object being studied systematically, both regarding the facts, characteristics and various things related to the research theme.

Qualitative analysis is considered more appropriate in this study, because this analysis is expected to make it more possible to develop this research in order to gain a deeper understanding.

Data processing in this study uses a critical-analytical method, namely analyzing and interpreting data about the boarding school system as a means of regeneration in the development of $d a^{\prime} w a h$.

This study tries to explain the form of activities carried out by Islamic educational institutions, especially Islamic boarding schools in preparing their sara santri to become $d a^{\prime} w a h$ successors cadres. Various rules conceptualized to develop $d a^{\prime} w a b$ are also applied such as togetherness, simplicity, individual character and organization. Thus, the activities in the boarding school are always aimed at internalizing Islamic values in the students.

So that the form of regeneration in developing da'wah in Islamic boarding schools is a cadre that is deliberately designed in such a way that the students who later graduate can develop their knowledge and be ready to preach Islamic values wherever they are in the form of da'wah.

\section{RESULTS AND DISCUSSION}

Pondok pesantren is an educational institution, has a function as a $d a^{\prime} w a b$ institution, and is an appropriate means of carrying out a cadre of prospective $d a^{\prime} i$. pondok pesantren certainly has elements and systems that are ideal in producing future $d a^{\prime} i$ cadres who have good knowledge and knowledge.

Islamic boarding schools as a means of regeneration in the development of da'wah, including: (a) Islamic boarding schools as a central facility for the development of the potential of the santri to the community and organize the social environment when they finish boarding; (b) Islamic boarding schools as information centers for Islam, which can be useful for the community to obtain certain products; (c) Islamic boarding schools as a forum for discussion of figures, for the community together with the kyai they can try to solve socio-cultural problems; (d) Islamic boarding schools as a center for various knowledge, as a place for prospective students from various communities; and (e) Apart from being a means of kaferisasi for students in the development of $d a^{\prime} w a h$, Islamic boarding schools can also function as a means of family tourism, including: public libraries, mini museums, and integrated farms, as well as living pharmacy plants.

The implementation stage of the regeneration of preachers at the Ar-Risalah Tegal Panjang Cariu Bogor boarding school includes three competency stages, namely first, basic competencies 
such as character and moral training, cultivation of faith values, and tawadhu' value training, the second general competence includes training in speech procedures and mental training, the three special competencies include specific speaking skills, skills to explain speeches in an interesting and fun way.

As for the terms and conditions that must be possessed theoretically, among others: (a) Knowing the al Qur'an and the Sunnab of the Prophet as the main religion of Islam; (b) Having knowledge of Islam which is based on the Qur'an and Sunnah, interpretation, hadith knowledge and the history of Islamic culture; (c) Have knowledge that is a tool for da'wah such as da'wah techniques, psychology; (d) Understand the language of the ummah who will be invited to the path that is blessed by Allah SWT. Likewise, rhetoric and eloquence in speaking or writing; and (e) Supporting and graceful, if he is stern and narrow-sighted, then a man will be born leaving him.

Da'wah can be carried out in four kinds of activities, namely: (a) Yad'una ilal Khairi, namely conveying and calling on humans to accept and practice the teachings of Islam in their entire life, with the belief that the da'wah of Islam is the only da'wah for all mankind who can convey the happiness of true life and become a source of goodness and truth (al-khair) which is no doubt; (b) Al-Amar bi al-Ma'ruf, namely ordering people, especially those who accept and embrace Islam as a way of life to do good, namely all things that are pleased by Allah SWT. In the form of words and thoughts that can provide benefits and benefits to humans, both individuals and society; (c) An-Naby an al-Munkar, which is preventing or hindering every form of munkar or every case that is not pleased by Allah SWT. If done, it can bring harm and disaster to all humans and society; and (d) Taghyiru al-Munkar, namely eradicating or changing and eliminating various munkar in human life, by devoting all abilities and abilities of each, so that this evil disappears from the midst of human life.

Some elements are very important to note. The elements of the da'wah are: (a) Recipient of $d a^{\prime} w a h$, namely a human or a group or community at large; (b) The content of da'wah, namely the views and goals of Islamic life which includes amar ma'ruf nabi munkar in various fields of human life; and (c) Da'wah media, namely modern mass communication tools today such as: newspapers, radio, television and social media/internet.

The kinds of $d a^{\prime} w a h$ are divided into 3, namely: the oral call of the word, the call of the bil Qalam, and the da'wah bil Hal.

a. Da'wah bil Oral. In the al-Qur'an it states that with ahsan a qaulu (speech) and good deeds. Who is better said than someone who calls to Allah, does righteous deeds, and says: "Surely I am a surrender?" (Surah Fushihlat $\{41\}$ : 33). [18]

The $d a^{\prime} w a h$ that is expressed in the verse is not only preaching with a verbal or oral dimension but also da'wah with good deeds (uswah) as exemplified by the Prophet.

What is meant by verbal bill is calling, calling on the path of Allah SWT. For the happiness of the world and the hereafter using language ( $\mathrm{mad}^{\prime} u$ ), calling to the way of Allah SWT., For the happiness of human beings in the world and the hereafter with real human actions.

b. Da'wah bil Qalam. Da'wah bil qalam is da'wah through writing which is done with writing expertise in newspapers, magazines, books, and social media/internet. The reach that can be reached by the da'wah bil qalam is wider than through verbal, so the method used does not require special time for its activities. Whenever and wherever your mad'u or object can enjoy the da'wah bil qalam offerings. 
c. Da'wah bil Hal. Da'wah bil hal is preaching by using deeds or examples as the message. Da'wah bil is also called natural da'wah. That is, by using messages in the form of deeds, da'wah is carried out as an effort to eradicate kungkaran directly (physically) or indirectly to uphold ma'ruf (goodness) such as building mosques, schools or anything that is easy to do and has the character of realizing the implementation of Allab's law. from all aspects.

\section{CONCLUSION}

Islamic boarding schools are community-based educational institutions established by individuals, foundations, Islamic community organizations, and/or communities that instill faith and piety in Allah SWT., Promote noble morals and uphold the adherence to the teachings of Islam rahmatan lil'alamin which is reflected in attitude of humility, tolerance, balance, moderation, and other noble values of Banda Indonesia through education, Islamic preaching, exemplary, and community empowerment within the framework of the unitary state of the Republic of Indonesia.

Education at the Ar-Risalah Tegal Panjang Cariu boarding school in Bogor is something that cannot be separated from da'wah because in the preaching itself there are elements of education, both teaching and change. Education is not only one of the processes in preaching but becomes an important thing or part even since the regeneration process or preparing a new generation who will continue the da'wah baton. Education becomes very urgent where in preparing $d a^{\prime} w a h$ cadres, it is necessary to strengthen knowledge and knowledge so that these cadres can continue the $d a^{\prime} w a b$ path properly and not mislead. The role of Islamic education institutions in addition to being a means of gaining knowledge for cadres is also a place to develop the abilities or skills needed in preaching such as the ability to speak (speech) in public, the ability to organize and lead, the ability to socialize and mingle and other abilities can become supporting competences. in preaching. The cadre that is carried out indirectly by educational institutions through conceptual activities makes cadre candidates consciously and unconsciously prepared to become prospective proselytizing candidates in the future.

Islamic boarding school as a means of regeneration is a place to train prospective $d a^{\prime} i$ as the next generation of organizations in the future, by providing knowledge and skills about leadership and management as well as knowledge and insight. The regeneration process is a long step that must be carried out in stages with careful planning. While the model or form of cadre preaching the development of preaching in the boarding school Ar-Risalab Tegal Panjang Cariu Bogor deliberately designed in such a way, certainly preachers cadres can develop the knowledge and technology obtained and are ready to preach Islamic values wherever located.

\section{REFERENCES}

[1] http://www.indonesia.go.id, accessed, 08-May-2020.

[2] Mastuhu. (2014). Dynamics of Islamic Boarding School Education System. (Jakarta: INIS XX), p. 34

[3] Suisyanto, (2016), Introduction to the Philosophy of Da'wah. (Yogyakarta: Teras), p. 63

[4] Hotman, A. Ilyas Ismail and Prio, (2011), Philosophy of Da'wah, Engineering Development of Religion and Islamic Civilization, (Jakarta: Kencana), p. 12.

[5] Pimay, Awaluddin, (2015), Paradigm of Humanist Da'wah, (Semarang: Rasail), p. 13

[6] Maunah, (2019), Santri Intellectual Tradition, (Yogyakarta: Teras), p. 26.

[7] Law number 18 of 2019, Concerning Islamic Boarding Schools.

[8] https://salamadian.com/pengentuk-sarana-dan-prasarana/ accessed July 25, 2020

[9] (bttp://kbbi.web.id/kader. akses 24 April 2020). 
Islamic Boarding Schools As Means Of Regeneration In The Development Of Da'wah Fauzi

[10] Law of the Republic of Indonesia number 18 of 2002, concerning Development.

[11] Pimay, Awaluddin, (2015), Paradigm of Humanist Da'wah, (Semarang: Rasail), p. 2

[12] AS, Enjang and aliyudin, (2019), Fundamentals of Da'wah Science, (Widya Padjajaran), p. 27

[13] Students document for the year 2020/2021 class, (Bogor: Ar-Risalah Islamic boarding school)

[14] Furchan, Arif, (2012), Introduction to Qualitative Research, (Surabaya: National Business), p. 21 